Review

International Journal of Biological Sciences

ISSN 1449-2288 www.biolsci.org 2008 4(3):161-168

CIvyspring International Publisher. All rights reserved

\title{
The Role of Erythropoietin as an Inhibitor of Tissue Ischemia
}

\author{
Nikolaos Paschos, Marios G. Lykissas and Alexandros E. Beris \\ Department of Orthopaedic Surgery, University of Ioannina School of Medicine, Ioannina, P.O. Box 45110, Greece.
}

Correspondence to: Marios G. Lykissas, MD, Department of Orthopaedic Surgery, University of Ioannina School of Medicine, Ioannina, 45110, Greece. Tel.: +30-26510-97472; Fax:+30-26510-34816; E-mail: mariolyk@yahoo.com

Received: 2008.03.02; Accepted: 2008.06.09; Published: 2008.06.10

Erythropoietin is a hypoxia-induced cytokine that stimulates erythropoiesis through the promotion of erythroid precursor cell proliferation and differentiation. Recent evidence supports that erythropoietin has a broad spectrum of tissue protecting actions affecting other systems than hemopoietic. Lately, research has focused on the nonhemopoietic effects of erythropoietin against tissue ischemia due to the unexpected observations of erythropoietin receptor expression by various cells, such as endothelial cells, neuronal cells, cardiac myocytes, and vascular smooth muscle cells. It has been shown that erythropoietin exerts its cardioprotective action during cardiac ischemic injury through reducing the infract size and enhancing new vessel formation over a longer time frame. Erythropoietin plays a crucial role in neuroprotection in many types of ischemic injury in the central and the peripheral nervous system. It is also strongly believed that erythropoietin exhibits a critical role in many other disorders that are pathogenetically related to acute tissue ischemia. This article reviews the proposed implications of erythropoietin in tissue ischemia and discusses the possible mechanisms for this action along with its potential therapeutic applications.

Key words: erythropoietin, ischemia, nervous system, cardiovascular system, ischemia/reperfusion injury

\section{Introduction}

Erythropoietin is a 165 aminoacid glycoprotein hormone with approximately $30 \mathrm{kD}$ molecular weight. It is synthesized primarily by kidneys in adults and by kidneys and liver in the fetus. The ratio between kidney and liver erythropoietin in the adult is 9:1 [1]. Its primary role involves prevention of programmed cell death (apoptosis) of erythrocyte precursors [2]. Erythropoietin induces erythropoiesis by promoting proliferation and differentiation of erythroid progenitor cells with the main target cell being the colony-forming unit erythroid (CFU-E). Although erythropoietin is the main regulator of this process, other growth factors, such as granulocyte colony-stimulating factor (G-CSF), stem cell factor (SCF), interleukins IL-1, IL-3, IL-6 IL-4, IL-9, and IL-11, granulocyte-macrophage (GM)-CSF, and insulin growth factor-1 (IGF-1) are believed that contribute in different levels of maturation of the erythrocyte $[3,4]$.

Erythropoietin gene expression is regulated mainly by hypoxia [5, 6]. Hypoxia-inducible factors (HIF) 1, 2 and 3, as well as nuclear factor kappa B (NF-kB) are the key regulators of erythropoietin gene expression [7]. Recent data revealed that hypoxia-inducible factor $2 \mathrm{a}$ (HIF-2a) has prominent role in controlling erythropoietin gene expression in hepatic cells $[8,9]$. According to some investigators this role of HIF-2a may be also applied in other tissues $[10,11]$.

In addition to its well known effect on red blood cell mass in response to changes in tissue oxygenation, many investigations have shown that erythropoietin also exerts protective role against tissue ischemia. It is believed that this is achieved both directly by activating multiple biochemical mechanisms that provide antiapoptotic, antioxidative, and anti-inflammatory response to hypoxia/anoxia and indirectly via its angiogenic potential by inducing oxygen systematic supply to the ischemic tissue.

This article reviews the proposed implications of erythropoietin in tissue ischemia and discusses the possible mechanisms for this action along with its potential therapeutic applications.

\section{Non Erythropoietic Role of Erythropoietin}

Erythropoietin has a broad spectrum of tissue protecting actions affecting other systems than hemopoietic [12-15]. Beginning with the unexpected observations of erythropoietin receptor (Epo-R) expression by various cells, such as endothelial cells, neuronal cells, cardiac myocytes, and vascular smooth muscle cells [16-19], research lately focused on the nonhemopoietic effects of erythropoietin and its potential use against tissue ischemia. 


\section{Cardiovascular System}

Erythropoietin exerts its cardioprotective action during cardiac ischemic injury through reducing the infract size and enhancing new vessel formation over a longer time frame [20]. It is well known that erythropoietin induces vasoconstriction-dependent hypertension and stimulation of angiogenesis in erythropoietin-treated animals and humans [21]. The effect of erythropoietin in blood pressure has been extensively described in the past after the initiation of treating anemia in chronic renal failure patients [22-24]. The exact mechanism remains unclear, though, different hypotheses involving cyclooxygenase-dependent endothelium derived contracting factors (EDCFs), stimulation of vascular cell growth, endogenous vasodilatory factors, and a direct angioconstrictive action of erythropoietin have been described [25, 26]. Erythropoietin effect on heart disorders has been showed that involves a mechanism with greater immediacy than that of direct oxygen supply due to haemoglobin levels increase [27].

Silverberg et al. [28] evaluated the influence of recombinant erythropoietin in patients with chronic cardiac failure and suggested that erythropoietin usage improves both cardiac and renal function, while it decreases mortality rates and hospitalization due to heart failure. Similar observational studies in the past, have reported better clinical outcome, improvement of survival and lower complication rate when erythropoietin is administrated to patients undergoing hemodialysis in order to normalize haemoglobin levels $[29,30]$. On the contrary, recent evidence from randomised trials showed an increased risk of cardiovascular events and increased mortality in the same patient group [31,32]. Bearing in mind the high cost of erythropoietin treatment and the insecure outcome in patient life expectancy, scepticism over the benefits of excessive use of erythropoietin is necessary.

Erythropoietin exerts both acute and long term cardioprotective effects through its receptor. In vitro studies have shown that Epo- $\mathrm{R}$ is expressed in various cell lines originated from the cardiovascular system $[16,33,34]$. The presence of Epo- $R$ was demonstrated in rat cardiac myocytes where the administration of erythropoietin prevented apoptosis by activating phosphatidylinositol 3 kinase (PI3-K)/Akt intracellular pathway [33]. According to Depping et al. [35] the expression of Epo-R was confirmed in ventricular myocytes and endothelial cells in adult human heart.

Apoptotic mechanisms are considered to be associated with crucial cardiac cell death following myocardial infraction that potentially is complicated with cardiac failure [36,37]. Inhibition of apoptosis has been strongly correlated with erythropoietin-mediated cardioprotection against acute ischemic injury. The antiapoptotic effects of erythropoietin have been associated with the inactivation of Bcl-2 associated death-promoting protein (BAD) through PI3-K/Akt pathway as well as the increased expression of the antiapoptotic proteins Bcl-2 and Bcl-xL [20, 38]. In a rat isolated-heart model, pre-treatment with erythropoietin increased the functional recovery of hearts during ischemia/reperfusion injury [39]. Further studies showed that specific pathways, such as PI3-K/Akt, mitogen-activated protein kinase (MAPK) pathways and protein kinase $\mathrm{C}(\mathrm{PKC})$ are implicated in erythropoietin cardioprotective action before, during or after ischemia [40-42].

Although apoptosis prevention is a main mechanism for erythropoietin acute cardioprotection, the role of nitric oxide (NO), a modulator of vascular tone and inhibitor of processes involved in atherothrombosis, should also be considered [43-45]. The endothelial isoform of $\mathrm{NO}$ is the prevailing form in the cardiovascular system. Endothelial nitric oxide synthase (eNOS) is activated by the signal transducer and activator of transcription-5 (STAT-5) and RAS/MAPK signalling molecules. In a transgenic mice model overexpressing human erythropoietin, the authors demonstrated fail to develop hypertension and myocardial infraction [46]. This was attributed to up-regulation of eNOS expression, increased NO production, and NO-mediated vascular relaxation compared to wild type animals.

Long-term protection of ischemic myocardium by erythropoietin is attributed to both new vascular formations by directly enhancing angiogenesis and increased vasculogenesis from endothelial progenitor cells (EPCs) [20]. It has been found that erythropoietin promotes EPC mobilization which in turn was associated with neovascularization of ischemic tissue [47]. Interestingly, the number of circulating EPCs in patients with coronary artery disease was significantly correlated with serum levels of erythropoietin [47]. Moreover, erythropoietin promotes NO synthesis in EPCs and reendothelialization of injured arterial vessels [48].

High-dose chronic erythropoietin treatment may result to increased hematocrit associated side effects, such as hypertension and thromboembolism. Enhancement of erythropoietin cardiac tissue protective activity without increasing the number of red blood cells is the key in the management of heart disorders.

\section{Nervous System}

It has been shown that special pathways for erythropoietin and its receptor are present not only in the central nervous system but also in the peripheral nerves, cerebrospinal fluid, and the retina [49-53]. 
Erythropoietin is suggested to be a cytokine with a neurotrophic and a neuroprotective role in the central and peripheral nervous system. Several studies have shown the neuroprotective action of erythropoietin $[13,14]$, while others have demonstrated that erythropoietin may facilitate nerve regeneration after peripheral nerve injury [54]. This role in neural system appears to resemble the actions of erythropoietin in progenitor cells of the hematopoietic tissue and is thought to be multifactorial. Hypoxia and neurological damage enhance erythropoietin and Epo-R production in the central nervous system [52, 55, 56]. HIF-1, a member of the PAS (PER/arylhydrocabon-receptor nuclear translocator/single minded) family of hypoxia-regulated transcription factors is the main factor responsible for hypoxia-mediated induction of erythropoietin expression in the retina [57].

Despite previous evidence it is now believed that erythropoietin crosses the blood-brain barrier in an injured brain [58]. This evolution confirms the importance of erythropoietin role in the initial treatment of the acutely injured nervous tissue. Furthermore, it offers an effective treatment for these conditions, since its intravenously or subcutaneous administration provides effective and targeted therapy. In addition, the results from the administration of recombinant human erythropoietin (rhEpo) in acute stroke patients confirmed exultantly both its safety and effectiveness in protecting cerebral tissue from ischemia [59].

Several hypotheses have been proposed in order to explicate the neuroprotective role of erythropoietin. Erythropoietin exhibits neurotrophic, anti-inflammatory, and antioxidant action [14, 49, 60-63]. It has been shown that it decreases susceptibility to glutamate toxicity $[64,65]$ and promotes apoptosis through induction of apoptotic agents [14, 51, 62-65]. Erythropoietin reduces nitric oxide-mediated injury [66-68], with its protective role on glia [69-71]. The improvement of blood flow to the injured tissue is a further potential mechanism of erythropoietin's protective role in the nervous system.

When a single molecule of erythropoietin binds its receptor enzymic phosphorylation of PI3-K and the nuclear factor NF-kB occurs. NF-kB, which is activated by erythropoietin after oxidotic stress [67], is an inflammatory reaction genes regulator [72]. Erythropoietin activates JAK2, which in turn activates NF-kB resulting in increased expression of apoptosis inhibiting genes, such as XIAP and c-IAP2. Activation of Akt by erythropoietin inhibits various metabolic paths that are connected to cell death, such as those which are related to glycogen synthetase kinase $3 \beta$ (GSK3 $\beta$ ), related to BAD, caspase-9, etc [73]. Furthermore, JAK2 induces activation by phosphorylation of Jun kinase
(JNK) and signal transducers and activators of transcription-5 (STAT-5) [74, 75]. STAT-5 enters the nucleus and induce transcription of genes involved with inhibition of apoptosis, such us Bcl- $x_{L}$ genes [74].

In the recent years, increasing knowledge of the nervous system physiology allowed the analysis of the pathogenetic mechanisms involved in various abnormal conditions. Disorders such as early brain injury, attention deficit hyperactivity disorder, and retinopathy of prematurity have been etiologically related to hypoxia. Erythropoietin actions seem to reverse this hypoxia-induced sequelae. A recent study proposed potential benefit by erythropoietin administration in patients with various psychiatric disorders [76]. Such an ischemic etiological profile may alternate not only the treatment approach used so far, but could also develop a new dynamic in the research of pathogenetic factors of vague disorders, such as Alzheimer's disease.

\section{Other Roles Proposed for Erythropoietin}

Based on observations on the role of erythropoietin in other tissues, it is strongly believed that erythropoietin plays a critical role in disorders that are pathogenetically related to acute tissue ischemia.

Erythropoietin has been used in the past for correcting both cancer and chemotherapy induced anemia [77-80]. Furthermore, the treatment outcome of both radiotherapy and chemotherapy in cancer patients receiving erythropoietin seems to be superior based on the beneficial effects of erythropoietin to tumour hypoxia [81]. However, the expression of erythropoietin receptor in neoplasmatic cells initially raised the question whether erythropoietin promotes tumour growth. Recently, Hamadmad and Holh [82] demonstrated that erythropoietin induces chemotaxis of cancer cells via MAPK/Erk and Rho/RhoA kinase pathways. These reports are in accordance with the finding from a trial conducted by Leyland-Jones et al. [83] where the usage of erythropoietin for the treatment of anemia in metastatic breast cancer patients resulted in decreased survival. In the same study, the primary cause of death in erythropoietin group was disease progression, significantly higher than the control group.

Although these reports are not debating the positive affects of erythropoietin, they make the need for further research in this field essential [84]. A recent meta-analysis confirmed the increased risk of venous thromboembolism and increased mortality rates after erythropoietin administration [85]. Safety concerns over the usage of erythropoiesis stimulating agents in treating anemia in patients with cancer are well established. Understanding the mechanism of the exact role of erythropoietin in neoplasmatic cells would possibly 
clarify these issues and potentially indicate alternative therapeutic measures against cancer.

The protective role of erythropoietin in tissue ischemia extended the investigation of the potential role of erythropoietin in other conditions related with ischemia. In critical ill patients, erythropoietin has been proposed as an ameliorator of the clinical outcome [86]. Studies suggesting the role of erythropoietin in survivor of skin and muscular flaps in animal studies magnify the significance of this cytokine in trauma patients $[87,88]$.

Although erythropoietin failed to reduce red blood cell transfusions in critically ill patients, it finally declined mortality in this group of patients with a higher decrease applied in trauma patients [86]. Since there was no difference in blood transfusion rate, the decrease in the mortality rate is not considered as a consequence of blood transfusion. The contribution of a nonhematopoietic mechanism in the superior mortality rate in erythropoietin treated patients is believed by the authors to be logical explanation to this contradictory event.

The presence of erythropoietin receptor in retina establishes a major role to erythropoietin in the treatment of several pathologic conditions etiological related to ischemia in these highly oxygen dependent tissue. Despite the discouraging results reported in non randomised trials exploring the results of erythropoietin in retinopathy [89], a new dynamic has been developed as knowledge on erythropoietin and nervous system advances [90]. Further study is needed in order to clarify the role of this ischemia protective cytokine in conditions, such as diabetic retinopathy and retinopathy of prematurity.

The role of angiogenic potential on survival of various flaps after erythropoietin administration has been extensively investigated. It is known that erythropoietin results in neovascularization and increased healing through stimulation of endothelial cell mitosis [88]. According to Jaquet et al. [91] erythropoietin found to have equal angiogenic potential with vascular endothelial growth factor (VEGF) which was confirmed by histologic evaluation on flaps. Moreover, exogenous administration of erythropoietin stimulated angiogenesis by day 3 in a genetically diabetic mouse model by increasing VEGF mRNA and protein expression [92]. However, Kim et al. [93] supported that the angiogenic potential of erythropoietin is unlikely to occur in the first 24 hours and therefore is not sufficient enough to explain the protective effect of erythropoietin on ischemia/reperfusion injury in their rat transverse rectus abdominis musculocutaneous (TRAM) flap model.
Novel erythropoiesis stimulating protein (NESP) or darbepoetin alfa has been introduced for the treatment of anemia in several conditions with comparable results with those of erythropoietin. It has a different pharmacokinetic profile from erythropoietin that allows less frequent administration in order to maintain similar haemoglobin levels [94-98]. Since the mechanism of action of NESP is relevant to the one of erythropoietin, its role in other tissues remains to be explored. Further study is needed before establishing the exact role of both erythropoietic inducing factors in tissue ischemia. Based on the disadvantages of high cost and potential low safety profile of recombinant erythropoiesis-stimulating agents in some patient groups, the potential benefit of interfering in erythropoietin gene expression through HIF-2 mechanisms emerges as an alternative for the treatment of certain types of anemia.

\section{Erythropoietin in Ischemia/Reperfusion In- jury}

Reperfusion injury is defined as the tissue injury following restoration of blood flow to an ischemic region. Ischemia/reperfusion-induced injury is characterized by a greater rate of tissue damage than the original ischemic insult itself and it is thought to be the result of the acute interruption of blood flow within the microcirculation. The injury is attributed to a complex interaction between neutrophils and endothelial cells when the formers release enzymes, free radicals, and cytokines [99]. This cascade usually leads to endothelium destruction, capillary obstruction, and finally to impairment of oxygen supply to the tissue [100-103].

Many studies have demonstrated that erythropoietin has a protective effect on tissue injury associated with ischemia/reperfusion injury in many tissues, including brain, retina, cardiac, liver, kidney, lung, and intestine [104-109]. This erythropoietin mediated protective effect against ischemia/reperfusion injury has been related to its antiapoptotic, antioxidative, and antiiflammatory properties.

Although apoptosis serves to eliminate dying cells in proliferating or differentiating cell populations [110], inappropriate induction of programmed cell death in pathologic conditions, such as ische$\mathrm{mia} /$ reperfusion injury, results in tissue dysfunction. Previous studies have shown that rhEpo protects against the ischemia/reperfusion injury, mainly through its antiapoptotic action [105, 109, 111]. According to Brimes and Gerami [112], the mechanism mediating the antiapoptotic effects of erythropoietin probably incudes the JAK2-STAT-Bcl-2 pathway. 
Bcl-2 may also be responsible for the antioxidant activity of erythropoietin [67]. It is believed that erythropoietin exhibits its antioxidant action either directly through the scavenging action of its sugar-moiety or indirectly by activating antioxidant enzymes, such as catalase (CAT), superoxide dismutase (SOD), and glutathione peroxidase (GSH-Px) [109, 113-118]. In an intestinal ischemia/reperfusion injury model in rats, Guneli et al. [109] revealed that although enzymatic activity of SOD and GSH-Px was not significantly changed after intraperitoneal administration of erythropoietin, significant alterations were obtained in the level of CAT activity. The authors concluded that erythropoietin may be capable to increase the activity of the antioxidant system via the increase or restoration of CAT levels which decreases due to ischemia/reperfusion injury.

Oxidative stress is an important determinant in the pathogenesis of ischemia/reperfusion injury. Accumulation of activated neutrophils at the injury site triggers the inflammatory cascade through the production of various cytotoxic proteins which in turn promote the radical induced ischemia/reperfusion injury [119-121]. Erythropoietin by suppressing the inflammatory response after the ischemia/reperfusion injury seems to be a protective agent in tissues subjected to this type of damage [65, 122, 123]. Erythropoietin mediated neutropenia reversal following reperfusion is believed to be the underlying mechanism for the inhibition of neutrophil recruitment in the inflamed tissue.

The role of erythropoietin on eNOS is still controversial. It is supported that although eNOS-derived NO may play a protective role at the onset of ische$\mathrm{mia} /$ reperfusion injury, the superoxide anions produced during oxidative stress may react with $\mathrm{NO}$ and turn it into oxidant peroxynitrite which is cytotoxic $[124,125]$. Many authors have shown that eNOS production and eNOS-derived NO overproduction is decreased after erythropoietin administration [66, 109, 126-128]. However, other investigators have reported increased expression of eNOS after erythropoietin therapy [129]. Therefore, before direct conclusions can be made, the role of erythropoietin in eNOS expression after ischemia/reperfusion injury should be elucidated.

\section{Conclusion}

Erythropoietin is believed to serve a manifold role in several tissues with the primary target being the protection from ischemia. It acts both by ensuring adequate oxygen supply through its role to erythropoiesis but also it intervenes directly to the tissue targets with multiple set of actions that reserve cell survivor through its nonhematopoietic effects. Further research would provide us with evidence that could alter the way erythropoietin is currently used in the clinical practice.

\section{Conflict of interest}

The authors have declared that no conflict of interest exists.

\section{References}

1. Fandrey J. Oxygen-dependent and tissue-specific regulation of erythropoietin gene expression. Am J Physiol Regul Integr Comp Physiol. 2004;286:R977-88.

2. Fisher JW, Koury S, Ducey T, et al. Erythropoietin (Epo) production by interstitial cells of hypoxic monkey kidneys. Br J Haematol. 1996;95:27-32.

3. $\mathrm{Wu} \mathrm{H}$, Klingmuller $\mathrm{U}$, Besmer $\mathrm{P}$, et al. Interaction of the erythropoietin and stem-cell-factor receptors. Nature. 1995;377:242-6.

4. Lin CS, Lim SK, D'Agati V, et al. Differential effects of an erythropoietin receptor gene disruption on primitive and definitive erythropoiesis. Genus Dev. 1996;10:154-64.

5. Wenger RH. Mammalian oxygen sensing, signalling and gene regulation. J Exp Biol. 2000;203:1253-63.

6. Maxwell PH, Pugh CW, Ratcliffe PJ. Inducible operation of the erythropoietin $3^{\prime}$ enhancer in multiple cell lines: evidence for a widespread oxygen-sensing mechanism. Proc Natl Acad Sci USA. 1993;90:2423-7.

7. Jelkmann W. Molecular biology of erythropoietin. Intern Med. 2004;43:649-59.

8. Rankin EB, Biju MP, Liu Q, et al. Hypoxia-inducible factor-2 (HIF-2) regulates hepatic erythropoietin in vivo. J Clin Invest. 2007;117:1068-77.

9. Ratcliffe PJ. HIF-1 and HIF-2: working alone or together in hypoxia? J Clin Invest. 2007;117:862-5.

10. Scortegagna $M$, Ding $K$, Zhang $Q$, et al. HIF-2alpha regulates murine hematopoietic development in an erythropoietin-dependent manner. Blood. 2005;105:3133-40.

11. Morita M, Ohneda O, Yamashita T, et al. HLF/HIF-2alpha is a key factor in retinopathy of prematurity in association with erythropoietin. EMBO J. 2003;22:1134-46.

12. Erbayraktar $\mathrm{S}$, de Lanerolle N, de Lotbinière A, et al. Carbamylated erythropoietin reduces radiosurgically-induced brain injury. Mol Med. 2006;12:74-80.

13. Sirén AL, Ehrenreich H. Erythropoietin-a novel concept for neuroprotection. Eur Arch Psychiatry Clin Neurosci. 2001;251:179-84.

14. Celik M, Gokmen N, Erbayraktar S, et al. Erythropoietin prevents motor neuron apoptosis and neurologic disability in experimental spinal cord ischemic injury. Proc Natl Acad Sci USA. 2002;99:2258-63.

15. Erbayraktar S, Grasso G, Sfacteria A, et al. Asialoerythropoietin is a nonerythropoietic cytokine with broad neuroprotective activity in vivo. Proc Natl Acad Sci USA. 2003;100:6741-6.

16. Anagnostou A, Liu Z, Steiner M, et al. Erythropoietin receptor mRNA expression in human endothelial cells. Proc Natl Acad Sci USA. 1994;91:3974-8.

17. Jelkmann W, Wagner K. Beneficial and ominous aspects of the pleiotropic action of erythropoietin. Ann Hematol. 2004;83:673-86.

18. Marti HH. Erythropoietin and the hypoxic brain. J Exp Biol. 2004;207:3233-42.

19. Ogilvie M, Yu X, Nicolas-Metral V, et al. Erythropoietin stimulates proliferation and interferes with differentiation of myoblasts. J Biol Chem. 2000;275:39754-61.

20. Lipsic E, Schoemaker RG, van der Meer P, et al. Protective effects of erythropoietin in cardiac ischemia: from bench to bedside. J 
Am Coll Cardiol. 2006;48:2161-7.

21. Vaziri ND. Cardiovascular effects of erythropoietin and anemia correction. Curr Opin Nephrol Hypertens. 2001;10:633-7.

22. Ono K, Hisasue Y. The rate of increase in hematocrit, humoral vasoactive substances and blood pressure changes in hemodialysis patients treated with recombinant human erythropoietin or blood transfusion. Clin Nephrol. 1992;37:23-7.

23. Muntzel M, Hannedouche T, Lacour B, et al. Effect of erythropoietin on hematocrit and blood pressure in normotensive and hypertensive rats. J Am Soc Nephrol. 1992;3:182-7.

24. Carlini R, Obialo CI, Rothstein M. Intravenous erythropoietin $(\mathrm{rHuEPO})$ administration increases plasma endothelin and blood pressure in hemodialysis patients. Am J Hypertens. 1993;6:103-7.

25. Vaziri ND. Mechanism of erythropoietin-induced hypertension. Am J Kidney Dis. 1999;33:821-8.

26. Wada Y, Matsuoka H, Tamai O, et al. Erythropoietin impairs endothelium-dependent vasorelaxation through cyclooxygenase-dependent mechanisms in humans. Am J Hypertens. 1999;12:980-7.

27. Van der Meer P, Voors AA, Lipsic E, et al. Erythropoietin in cardiovascular diseases. Eur Heart J. 2004;25:285-91.

28. Silverberg DS, Wexler D, Sheps D, et al. The effect of correction of mild anemia in severe, resistant congestive heart failure using subcutaneous erythropoietin and intravenous iron: a randomized controlled study. J Am Coll Cardiol. 2001;37:1775-80.

29. Ofsthun N, Labrecque J, Lacson E, et al. The effects of higher hemoglobin levels on mortality and hospitalization in hemodialysis patients. Kidney Int. 2003;63:1908-14.

30. Ma JZ, Ebben J, Xia H, et al. Hematocrit level and associated mortality in hemodialysis patients. J Am Soc Nephrol. 1999;10:610-9.

31. Drüeke TB, Locatelli F, Clyne N, et al. Normalization of hemoglobin level in patients with chronic kidney disease and anemia. N Engl J Med. 2006;355:2071-84.

32. Singh AK, Szczech L, Tang KL, et al. Correction of anemia with epoetin alfa in chronic kidney disease. $N$ Engl J Med. 2006;355:2085-98.

33. Tramontano AF, Muniyappa R, Black AD, et al. Erythropoietin protects cardiac myocytes from hypoxia-induced apoptosis through an Akt-dependent pathway. Biochem Biophys Res Commun. 2003;308:990-4.

34. Wright GL, Hanlon P, Amin K, et al. Erythropoietin receptor expression in adult rat cardiomyocytes is associated with an acute cardioprotective effect for recombinant erythropoietin during ischemia-reperfusion injury. FASEB J. 2004;18:1031-3.

35. Depping R, Kawakami K, Ocker H, et al. Expression of the erythropoietin receptor in human heart. J Thorac Cardiovasc Surg. 2005;130:877-8.

36. Saraste A, Pulkki K, Kallajoki M, et al. Apoptosis in human acute myocardial infarction. Circulation. 1997;95:320-3.

37. Olivetti G, Abbi R, Quaini F, et al. Apoptosis in the failing human heart. N Engl J Med. 1997;336:1131-41.

38. Chong ZZ, Kang JQ, Maiese K. Hematopoietic factor erythropoietin fosters neuroprotection through novel signal transduction cascades. J Cereb Blood Flow Metab. 2002;22:503-14.

39. Cai Z, Manalo DJ, Wei G, et al. Hearts from rodents exposed to intermittent hypoxia or erythropoietin are protected against ischemia-reperfusion injury. Circulation. 2003;108:79-85.

40. Cai Z, Semenza GL. Phosphatidylinositol-3-kinase signaling is required for erythropoietin-mediated acute protection against myocardial ischemia/reperfusion injury. Circulation. 2004;109:2050-3.

41. Shi Y, Rafiee P, Su J, et al. Acute cardioprotective effects of erythropoietin in infant rabbits are mediated by activation of protein kinases and potassium channels. Basic Res Cardiol. 2004;99:173-82.
42. Hanlon PR, Fu P, Wright GL, et al. Mechanisms of erythropoietin-mediated cardioprotection during ischemia-reperfusion injury: role of protein kinase $C$ and phosphatidylinositol 3-kinase signaling. FASEB J. 2005;19:1323-5.

43. Vanhoutte PM. The endothelium--modulator of vascular smooth-muscle tone. N Engl J Med. 1988;319:512-3.

44. Tharaux PL, Chatziantoniou C, Casellas D, et al. Vascular endothelin-1 gene expression and synthesis and effect on renal type I collagen synthesis and nephroangiosclerosis during nitric oxide synthase inhibition in rats. Circulation. 1999;99:2185-91.

45. De Caterina R, Libby P, Peng HB, et al. Nitric oxide decreases cytokine-induced endothelial activation. Nitric oxide selectively reduces endothelial expression of adhesion molecules and proinflammatory cytokines. J Clin Invest. 1995;96:60-8.

46. Ruschitzka FT, Wenger RH, Stallmach T, et al. Nitric oxide prevents cardiovascular disease and determines survival in polyglobulic mice overexpressing erythropoietin. Proc Natl Acad Sci U S A. 2000;97:11609-13.

47. Heeschen C, Aicher A, Lehmann R, et al. Erythropoietin is a potent physiologic stimulus for endothelial progenitor cell mobilization. Blood. 2003;102:1340-6.

48. Urao N, Okigaki M, Yamada H, et al. Erythropoietin-mobilized endothelial progenitors enhance reendothelialization via Akt-endothelial nitric oxide synthase activation and prevent neointimal hyperplasia. Circ Res. 2006;98:1405-13.

49. Morishita E, Masuda S, Nagao M, et al. Erythropoietin receptor is expressed in rat hippocampal and cerebral cortical neurons, and erythropoietin prevents in vitro glutamate-induced neuronal death. Neuroscience. 1997;76:105-16.

50. Marti HH, Wenger RH, Rivas LA, et al. Erythropoietin gene expression in human, monkey and murine brain. Eur J Neurosci. 1996;8:666-76.

51. Juul SE, Anderson DK, Li Y, et al. Erythropoietin and erythropoietin receptor in the developing human central nervous system. Pediatr Res. 1998;43:40-9.

52. Sirén AL, Knerlich F, Poser W, et al. Erythropoietin and erythropoietin receptor in human ischemic/hypoxic brain. Acta Neuropathol. 2001;101:271-6.

53. Campana WM, Myers RR. Erythropoietin and erythropoietin receptors in the peripheral nervous system: changes after nerve injury. FASEB J. 2001;15:1804-6.

54. Lykissas MG, Sakellariou E, Vekris MD, et al. Axonal regeneration stimulated by erythropoietin. An experimental study in rats. J Neurosci Methods. 2007;164:107-15.

55. Sadamoto Y, Igase K, Sakanaka M, et al. Erythropoietin prevents place navigation disability and cortical infarction in rats with permanent occlusion of the middle cerebral artery. Biochem Biophys Res Commun. 1998;253:26-32.

56. Bernaudin M, Marti HH, Roussel S, et al. A potential role for erythropoietin in focal permanent cerebral ischemia in mice. J Cereb Blood Flow Metab. 1999;19:643-51.

57. Grimm C, Wenzel A, Groszer M, et al. HIF-1-induced erythropoietin in the hypoxic retina protects against light-induced retinal degeneration. Nat Med. 2002;8:718-24.

58. Brines ML, Ghezzi P, Keenan S, et al. Erythropoietin crosses the blood-brain barrier to protect against experimental brain injury. Proc Natl Acad Sci U S A. 2000;97:10526-31.

59. Ehrenreich H, Hasselblatt M, Dembowski C, et al. Erythropoietin therapy for acute stroke is both safe and beneficial. Mol Med. 2002;8:495-505.

60. Campana WM, Misasi R, O'Brien JS. Identification of a neurotrophic sequence in erythropoietin. Int J Mol Med. 1998;1:235-41.

61. Kawakami M, Sekiguchi M, Sato K, et al. Erythropoietin receptor-mediated inhibition of exocytotic glutamate release confers neuroprotection during chemical ischemia. J Biol Chem. 2001;276:39469-75.

62. Renzi MJ, Farrell FX, Bittner A, et al. Erythropoietin induces 
changes in gene expression in PC-12 cells. Brain Res Mol Brain Res. 2002;104:86-95.

63. Silva M, Benito A, Sanz C, et al. Erythropoietin can induce the expression of bcl-x $(\mathrm{L})$ through Stat 5 in erythropoietin-dependent progenitor cell lines. J Biol Chem. 1999;274:22165-9.

64. Sirén AL, Fratelli M, Brines M, et al. Erythropoietin prevents neuronal apoptosis after cerebral ischemia and metabolic stress. Proc Natl Acad Sci U S A. 2001;98:4044-9.

65. Villa P, Bigini P, Mennini T, et al. Erythropoietin selectively attenuates cytokine production and inflammation in cerebral ischemia by targeting neuronal apoptosis. J Exp Med. 2003;198:971-5.

66. Calapai G, Marciano MC, Corica F, et al. Erythropoietin protects against brain ischemic injury by inhibition of nitric oxide formation. Eur J Pharmacol. 2000;401:349-56.

67. Digicaylioglu M, Lipton SA. Erythropoietin-mediated neuroprotection involves cross-talk between Jak2 and NF-kappaB signalling cascades. Nature. 2001;412:641-7.

68. Kumral A, Baskin H, Gokmen N, et al. Selective inhibition of nitric oxide in hypoxic-ischemic brain model in newborn rats: is it an explanation for the protective role of erythropoietin? Biol Neonate. 2004;85:51-4.

69. Nagai A, Nakagawa E, Choi HB, et al. Erythropoietin and erythropoietin receptors in human CNS neurons, astrocytes, microglia, and oligodendrocytes grown in culture. J Neuropathol Exp Neurol. 2001;60:386-92.

70. Sugawa M, Sakurai Y, Ishikawa-Ieda Y, et al. Effects of erythropoietin on glial cell development; oligodendrocyte maturation and astrocyte proliferation. Neurosci Res. 2002;44:391-403.

71. Vairano M, Dello Russo C, Pozzoli G, et al. Erythropoietin exerts anti-apoptotic effects on rat microglial cells in vitro. Eur J Neurosci. 2002;16:584-92.

72. Yamamoto Y, Gaynor RB. Role of the NF-kappaB pathway in the pathogenesis of human disease states. Curr Mol Med. 2001;1:287-96.

73. Lipton SA. Erythropoietin for neurologic protection and diabetic neuropathy. N Engl J Med. 2004;350:2516-7.

74. Jacobs-Helber SM, Ryan JJ, Sawyer ST. JNK and p38 are activated by erythropoietin (EPO) but are not induced in apoptosis following EPO withdrawal in EPO-dependent HCD57 cells. Blood. 2000;96:933-40.

75. Ihle JN. Cytokine receptor signalling. Nature. 1995;377:591-4.

76. Miskowiak K, O'Sullivan U, Harmer CJ. Erythropoietin enhances hippocampal response during memory retrieval in humans. J Neurosci. 2007;27:2788-92.

77. Abels RI. Recombinant human erythropoietin in the treatment of the anaemia of cancer. Acta Haematol. 1992;87:4-11.

78. Dunphy FR, Dunleavy TL, Harrison BR, et al. Erythropoietin reduces anemia and transfusions after chemotherapy with paclitaxel and carboplatin. Cancer. 1997;79:1623-8.

79. de Campos E, Radford J, Steward W, et al. Clinical and in vitro effects of recombinant human erythropoietin in patients receiving intensive chemotherapy for small-cell lung cancer. J Clin Oncol. 1995;13:1623-31.

80. Littlewood TJ, Bajetta E, Nortier JW, et al. Effects of epoetin alfa on hematologic parameters and quality of life in cancer patients receiving nonplatinum chemotherapy: results of a randomized, double-blind, placebo-controlled trial. J Clin Oncol. 2001;19:2865-74.

81. Razzouk BI, Hord JD, Hockenberry M, et al. Double-blind, placebo-controlled study of quality of life, hematologic end points, and safety of weekly epoetin alfa in children with cancer receiving myelosuppressive chemotherapy. J Clin Oncol. 2006;24:3583-9.

82. Hamadmad SN, Hohl RJ. Erythropoietin stimulates cancer cell migration and activates RhoA protein through a mitogen-activated protein kinase/extracellular signal-regulated kinase-dependent mechanism. J Pharmacol Exp Ther. 2008;324:1227-33.

83. Leyland-Jones B, Semiglazov V, Pawlicki M, et al. Maintaining normal hemoglobin levels with epoetin alfa in mainly nonanemic patients with metastatic breast cancer receiving first-line chemotherapy: a survival study. J Clin Oncol. 2005;23:5960-72.

84. Guan X, Chen L. Role of erythropoietin in cancer-related anaemia: a double-edged sword? J Int Med Res. 2008;36:1-8.

85. Bennett CL, Silver SM, Djulbegovic B, et al. Venous thromboembolism and mortality associated with recombinant erythropoietin and darbepoetin administration for the treatment of cancer-associated anemia. JAMA. 2008;299:914-24.

86. Corwin HL. Erythropoietin use in critically ill patients: forest and trees. C M A J. 2007;177:747-9.

87. Buemi M, Galeano M, Sturiale A, et al. Recombinant human erythropoietin stimulates angiogenesis and healing of ischemic skin wounds. Shock. 2004;22:169-73.

88. Buemi M, Vaccaro M, Sturiale A, et al. Recombinant human erythropoietin influences revascularization and healing in a rat model of random ischaemic flaps. Acta Derm Venereol. 2002;82:411-7.

89. Romagnoli C, Zecca E, Gallini F, et al. Do recombinant human erythropoietin and iron supplementation increase the risk of retinopathy of prematurity? Eur J Pediatr. 2000;159:627-8.

90. Juul SE, McPherson RJ, Bammler TK, et al. Recombinant Erythropoietin Is Neuroprotective in a Novel Mouse Oxidative Injury Model. Dev Neurosci. 2007 [Epub ahead of print].

91. Jaquet K, Krause K, Tawakol-Khodai M, et al. Erythropoietin and VEGF exhibit equal angiogenic potential. Microvasc Res. 2002;64:326-33.

92. Galeano M, Altavilla D, Cucinotta D, et al. Recombinant human erythropoietin stimulates angiogenesis and wound healing in the genetically diabetic mouse. Diabetes. 2004;53:2509-17.

93. Kim EK, Hong JP. The effect of recombinant human erythropoietin on ischemia-reperfusion injury: An experimental study in a rat TRAM flap model. Plast Reconstr Surg. 2007;120:1774-81.

94. Macdougall IC, Gray SJ, Elston O, et al. Pharmacokinetics of novel erythropoiesis stimulating protein compared with epoetin alfa in dialysis patients. J Am Soc Nephrol. 1999;10:2392-5.

95. Locatelli F, Olivares J, Walker R, et al. Novel erythropoiesis stimulating protein for treatment of anemia in chronic renal insufficiency. Kidney Int. 2001;60:741-7.

96. Macdougall IC, Roberts DE, Coles GA, et al. Clinical pharmacokinetics of epoetin (recombinant human erythropoietin). Clin Pharmacokinet. 1991;20:99-113.

97. Senecal FM, Yee L, Gabrail N, et al. Treatment of chemotherapy-induced anemia in breast cancer: results of a randomized controlled trial of darbepoetin alfa 200 microg every 2 weeks versus epoetin alfa 40,000 U weekly. Clin Breast Cancer. 2005;6:446-54.

98. Waltzman R, Croot C, Justice GR, et al. Randomized comparison of epoetin alfa (40,000 U weekly) and darbepoetin alfa (200 microg every 2 weeks) in anemic patients with cancer receiving chemotherapy. Oncologist. 2005;10:642-50.

99. Zamboni WA, Roth AC, Russell RC, et al. Morphologic analysis of the microcirculation during reperfusion of ischemic skeletal muscle and the effect of hyperbaric oxygen. Plast Reconstr Surg. 1993;91:1110-23.

100.Buras J. Basic mechanisms of hyperbaric oxygen in the treatment of ischemia-reperfusion injury. Int Anesthesiol Clin. 2000;38:91-109.

101.Cetinkale O, Bilgic L, Bolayirli M, et al. Involvement of neutrophils in ischemia-reperfusion injury of inguinal island skin flaps in rats. Plast Reconstr Surg. 1998;102:153-60.

102.Kerrigan CL, Stotland MA. Ischemia reperfusion injury: a review. Microsurgery. 1993;14:165-75.

103.Zimmerman GA, Prescott SM, McIntyre TM. Endothelial cell 
interactions with granulocytes: tethering and signaling molecules. Immunol Today. 1992;13:93-100.

104.Lipsic E, van der Meer P, Henning RH, et al. Timing of erythropoietin treatment for cardioprotection in ischemia/reperfusion. J Cardiovasc Pharmacol. 2004;44:473-9.

105.Sharples EJ, Patel N, Brown P, et al. Erythropoietin protects the kidney against the injury and dysfunction caused by ischemia-reperfusion. J Am Soc Nephrol. 2004;15:2115-24.

106.Solaroglu A, Dede FS, Okutan E, et al. A single dose of erythropoietin attenuates lipid peroxidation in experimental liver ischemia-reperfusion injury in the rat fetus. J Matern Fetal Neonatal Med. 2004;16:231-4.

107.Wu H, Ren B, Zhu J, et al. Pretreatment with recombined human erythropoietin attenuates ischemia-reperfusion-induced lung injury in rats. Eur J Cardiothorac Surg. 2006;29:902-7.

108.Junk AK, Mammis A, Savitz SI, et al. Erythropoietin administration protects retinal neurons from acute ischemia-reperfusion injury. Proc Natl Acad Sci U S A. 2002;99:10659-64.

109.Guneli E, Cavdar Z, Islekel H, et al. Erythropoietin protects the intestine against ischemia/ reperfusion injury in rats. Mol Med. 2007;13:509-17.

110.Kerr JF, Wyllie AH, Currie AR. Apoptosis: a basic biological phenomenon with wide-ranging implications in tissue kinetics. Br J Cancer. 1972;26:239-57.

111.Parsa CJ, Kim J, Riel RU, et al. Cardioprotective effects of erythropoietin in the reperfused ischemic heart: a potential role for cardiac fibroblasts. J Biol Chem. 2004;279:20655-62.

112.Brines M, Cerami A. Discovering erythropoietin's extra-hematopoietic functions: biology and clinical promise. Kidney Int. 2006;70:246-50.

113. Chattopadhyay A, Choudhury TD, Bandyopadhyay D, et al. Protective effect of erythropoietin on the oxidative damage of erythrocyte membrane by hydroxyl radical. Biochem Pharmacol. 2000;59:419-25.

114.Chakraborty M, Ghosal J, Biswas T, et al. Effect of erythropoietin on membrane lipid peroxidation, superoxide dismutase, catalase, and glutathione peroxidase of rat RBC. Biochem Med Metab Biol. 1988;40:8-18.

115.Genc S, Akhisaroglu M, Kuralay F, et al. Erythropoietin restores glutathione peroxidase activity in 1-methyl-4-phenyl-1,2,5,6-tetrahydropyridine-induced neurotoxicity in C57BL mice and stimulates murine astroglial glutathione peroxidase production in vitro. Neurosci Lett. 2002;321:73-6.

116.Kumral A, Tugyan K, Gonenc S, et al. Protective effects of erythropoietin against ethanol-induced apoptotic neurodegenaration and oxidative stress in the developing C57BL/ 6 mouse brain. Brain Res Dev Brain Res. 2005;160:146-56.

117.Sakanaka M, Wen TC, Matsuda S, et al. In vivo evidence that erythropoietin protects neurons from ischemic damage. Proc Natl Acad Sci U S A. 1998;95:4635-40.

118.Túri S, Németh I, Varga I, et al. The effect of erythropoietin on the cellular defence mechanism of red blood cells in children with chronic renal failure. Pediatr Nephrol. 1992;6:536-41.

119.Mallick IH, Yang W, Winslet MC, et al. Ischemia-reperfusion injury of the intestine and protective strategies against injury. Dig Dis Sci. 2004;49:1359-77.

120.Zimmerman BJ, Granger DN. Mechanisms of reperfusion injury. Am J Med Sci. 1994;307:284-92.

121.Kettle AJ, Winterbourn CC. Myeloperoxidase: a key regulator of neutrophil oxidant production. Redox Rep. 1997;3:3-15.

122. Contaldo C, Meier C, Elsherbiny A, et al. Human recombinant erythropoietin protects the striated muscle microcirculation of the dorsal skinfold from postischemic injury in mice. Am J Physiol Heart Circ Physiol. 2007;293:H274-83.

123.Liu X, Xie W, Liu P, et al. Mechanism of the cardioprotection of rhEPO pretreatment on suppressing the inflammatory response in ischemia-reperfusion. Life Sci. 2006;78:2255-64.

124.Roviezzo F, Cuzzocrea S, Di Lorenzo A, et al. Protective role of PI3-kinase-Akt-eNOS signalling pathway in intestinal injury associated with splanchnic artery occlusion shock. Br J Pharmacol. 2007;151:377-83.

125.Münzel T, Daiber A, Ullrich V, et al. Vascular consequences of endothelial nitric oxide synthase uncoupling for the activity and expression of the soluble guanylyl cyclase and the cGMP-dependent protein kinase. Arterioscler Thromb Vasc Biol. 2005;25:1551-7.

126.López Ongil SL, Saura M, Lamas S, et al. Recombinant human erythropoietin does not regulate the expression of endothelin-1 and constitutive nitric oxide synthase in vascular endothelial cells. Exp Nephrol. 1996;4:37-42.

127.Banerjee D, Rodriguez M, Nag M, et al. Exposure of endothelial cells to recombinant human erythropoietin induces nitric oxide synthase activity. Kidney Int. 2000;57:1895-904

128.Wang XQ, Vaziri ND. Erythropoietin depresses nitric oxide synthase expression by human endothelial cells. Hypertension. 1999;33:894-9.

129.Rui T, Feng Q, Lei M, et al. Erythropoietin prevents the acute myocardial inflammatory response induced by ische$\mathrm{mia} /$ reperfusion via induction of AP-1. Cardiovasc Res. 2005;65:719-27. 